Вестник ВГУ. Серия: Право

УДК 1 (091)

DOI https://doi.org/10.17308/vsu.proc.law.2020.4/3181

\title{
СПЕЦИФИКА ФИЛОСОФСКОГО ПОДХОДА К ПОНИМАНИЮ КОНФЛИКТА: ИСТОРИЯ И СОВРЕМЕННОСТЬ
}

\author{
Е. Н. Ищенко \\ Воронежский государственный университет \\ Поступила в редакцию 16 ноября 2020 г.
}

\begin{abstract}
Аннотация: представления об албивалентности конфбликта, его противоречивом характере играли особую роль в западной фблособбской традииии с молента ее возникновения. В совреленнол контексте новое концептуальное понилание конфблкта разрабатьвается в ралках фбллософии диалога.

Ключевые слова: агон, противоречие, диалектика, эристика, конфбликт, фьлософия диалога.
\end{abstract}

\begin{abstract}
: the notions of ambivalence of conflict and its contradictory nature have played a special role in Western philosophical tradition since its inception. In contemporary context a new conceptual understanding of conflict is proposed within the framework of philosophy of dialogue.

Key words: agon, contradiction, dialectics, eristic, conflict, philosophy of dialogue.
\end{abstract}

Представления об амбивалентности конфликта в его онтологическом, социальном и коммуникативном измерениях пронизывают западный философский дискурс с момента его возникновения. Противоречивый характер конфликта per se отчетливо просматривается в различных смысловых оттенках греческих слов, близких по значению возникшему позже латинскому conflictus. Истоки подобного положения дел стоит искать в специфических особенностях греческой культуры, породившей философию как способ критической рефлексии.

Выдающийся немецкий исследователь XIX в. Я. Буркхардт, который признан предтечей современной культуральной истории ${ }^{1}$ ввел в научный оборот понятие «агональность» (das Agonale) ${ }^{2}$. В трактовке Я. Буркхардта агональность есть один из ключевых концептов, своего рода культурная универсалия, позволяющая выработать целостное описание феномена греческой цивилизации. Борьба, состязание пронизывают различные сфреры общественной жизни, гармонизируя пространства профранного и сакрального. Греческая мифология, насыщенная мотивами противоборства богов и героев, тесно переплетается с реалиями жизни в полисе. Не случайно агон получает статус божества, а его визуальное выражение в

\footnotetext{
${ }^{1}$ См.: Берк П. Что такое культуральная история? 2-е изд. М., 2016. С. 19-20.

${ }^{2}$ Cм.: Janssen E. M. Jacob Burckchardt und die Griechen. Assen: Van Gorcum, 1979.

(c) Ищенко Е. Н., 2020
} 
виде скульптуры атлета с гантелями в руках пребывало в Олимпии с V в. до н. э. ${ }^{3}$ Многочисленные подтверждения духа агональности как способа бытия древнего грека мы находим в литературных памятниках эпохи. Так, в комедии Аристофана «Облака» среди действующих лиц присутствуют спорщики Правда и Кривда, схватка которых предваряется словами: «Теперь должны вы доказать / Ловких речей орудьем, / Игрой ума, мыслей дождем, / Блеском суждений острых, / Кто из двоих вправе прослыть / Красноречья мастером» ${ }^{4}$. Не случайно агон вошел в канон древнеаттической комедии как композиционный элемент, отражающий реалии греческой культуры.

Однако понятие агона заключает в себе различные смыслы. С одной стороны, агон понимается как честное, открытое состязание, в котором побеждает достойнейший, проявивший выдающиеся способности в той или иной сфере: спорте, музыке, театральном искусстве, пении и т. п. Такого рода соперничество предусматривало определенные правила и процедуры судейства, закрепленные традицией. В них равные демонстрировали свои достижения для выбора наилучших. С другой стороны, понятие «агон» использовалось и для обозначения борьбы с противником, задачей которой было его полное подавление и уничтожение. В подобной ситуации в принципе не существует правил и церемоний, восторжествовать должна лишь одна из сторон конфликта.

В контексте нашего рассмотрения исключительно важно отметить следующее обстоятельство. Расправа с противником предполагает не только его физическое уничтожение, буквально понятую войну с врагом. Не менее важным оказывалось уничтожение противоположной стороны в переносном смысле, моральное подавление в глазах большинства. В связи с распространенностью практики риторических баталий власть слова, проявляющаяся в агональной борьбе, стала предметом философского осмысления. Приведем известные сентенции Горгия: «Слово есть великий властелин, который, обладая весьма малым и совершенно незаметным телом, совершает чудеснейшие дела. <..> сила убеждения, которая присуща слову, и душу формирует, как хочет, это должно узнать $<\ldots>$... из словесных состязаний в народных собраниях, в которых [бывает что] одна речь, искусно составленная, но не соответствуюшая истине, [более всего] нравится народной массе и убеждает ее (курсив наш. - E. И.)»5. Манипулятивный потенциал словесного поединка нашел свое отражение в особой отрасли знания - эристике (греч. eristika - искусство спора), представлявшей собой совокупность практических приемов и правил. Аристотель определял ее как искусство рассуждения «лишь ради спора и желания одолеть». Столетия спустя А. Шопенгауэр точно

${ }^{3}$ Cм.: Smith W. Dictionary of Greek and Roman Biography and Mythology. Boston: Little, Brown and Company, 1867. P. 74.

${ }^{4}$ Аристоббан. Облака // Аристофан. Комедии. Фрагменты. М., 2008. С. 198.

${ }^{5}$ Цит. по: Маковельский А. О. Софисты. Вып. 1. Баку, 1940. Фр. 8.

${ }^{6}$ Аристотель. О софистических опровержениях // Аристотель. Соч. : в 4 т. М., 1978. T. 2. 


\section{Вестник ВГУ. Серия: Право}

проводит границу между различными стратегиями ведения полемики: «...истина спорного вопроса, взятая объективно, и сила правоты или резона в глазах спорящих и слушателей - вещи совершенно различные» ${ }^{7}$. Эристический дискурс в принципе снимал проблему существования истины. В его рамках конфликтность словесного поединка не могла разрешаться рождением новых идей. Эристика способствовала легитимации, закреплению позиции, которая была сформулирована заранее. Сократовский диалог, напротив, основывался на диалектическом сталкивании противоречий с целью достижения объективной истины.

Агональность греческой культуры проявлялась в сосуществовании множества философских школ, предлагавших различные картины мироустройства, многообразие подходов к их концептуализации. Диалектическая традиция, поставившая проблемы противоречия и конфликта в центр философокого осмысления, начинается с Гераклита. В дошедших до нас фрагментарных отрывках его сочинений, наполненных скорее образами, чем понятиями, метафора войны занимает особое место. Война как предельное выражение конфликта в равной мере способствует как уничтожению старого, так и торжеству нового. Метафора войны у Гераклита отражает саму суть Логоса, высшего закона бытия. Логос нельзя изменить, как нельзя отменить конфликт, его можно только познать. Более того, само устройство мира открывается человеку через предельную напряженную распрю, битву, высшую степень конфликтности. Из истока гераклитовской диалектики берет свое начало точка зрения на войну как двигатель прогресса, жестокий механизм внедрения нового и избавления от старого. Не случайно современный теоретик медиа Н. Больц в названии одной из глав своей книги «Азбука медиа» ${ }^{8}$ использует парафраз гераклитовского афоризма: «Война как мать всех медиа».

Однако в традиции греческой фрилософской мысли представлены также противоположные позиции. Исключение противоречия из сферы мысли у Парменида ведет к иной модели мира, в котором «бытие ведь есть, а ничто не есть». Вечность и неподвижность бытия не предполагают развития. Тождество бытия и мышления у Парменида не оставляют противоречию шанса быть включенным в область философрского размышления. Для Платона, отдавшего «мир вещей» на откуп гераклитовскому вечному становлению, возникновение конфликтов обязано двойственной природе человека, их исток коренится в алчности и зависти. Однако в «мире идей» все иначе, гармония не предполагает конфликта, борьбы противоречий. Для Платона «самое лучшее - это не война, не междоусобия: ужасно, если в них возникает нужда; мир же - это всеобщее дружелюбие» ${ }^{10}$. Но это не просто благое пожелание, поскольку Платон предлагает философрский

\footnotetext{
${ }^{7}$ Шопенгауэр А. Эристика или искусство побеждать в спорах. URL: https:// iknigi.net/avtor-artur-shopengauer/104359-eristika-ili-iskusstvo-pobezhdat-vsporah-artur-shopengauer/read/page-1.html (дата обращения: 20.10.2020).

${ }^{8}$ Больи Н. Азбука медиа. М., 2011.

${ }_{9}^{9}$ Фрагменты ранних греческих фрилософов. М., 1989. Ч. 1. С. 296.

${ }^{10}$ Платон. Законы // Платон. Собр. соч. : в 4 т. М., 1994. Т. 4. С. 75.
} 


\section{Междисциплинарное сотрудничество...}

проект идеального государства, предусматривающий воплощение идеи Блага как основания гармонии общественного бытия. В его пространстве частная собственность в высшем сословии, понимаемая как важнейший фрактор конфликтогенности, устранена. Сословные перегородки, за прочностью которых присматривает государство, берущее на себя миссию воспитания детей исключительно как будущих воинов, работников или правителей, надежно охраняют общество от проявлений зависти и алчности. В учении Платона агональность не исчезает, она переходит в другой регистр, в сферу духовной жизни. Спор между философами-правителями, возвышающий участников над обыденностью, позволяет достичь истины, придерживаясь майевтики Сократа.

В учении Аристотеля конфликт получает иную трактовку. «Соревнование как ревностное желание сравниться есть нечто хорошее и бывает у людей хороших, а зависть есть нечто низкое и бывает у людей низких ${ }^{11}$. Граница между «хорошим» и «плохим» конфликтом пролегает в области мотиваций, а двойственный характер конфликта как соревнования напрямую связан с моральными качествами участвующих в нем персонажей. Для Аристотеля полис есть единство непохожих, неравных в имущественном отношении. Поэтому конфликт есть неустранимая составляющая социальной жизни, которая может быть урегулирована в публичных спорах. Последние предполагают не искусное использование софистических уловок, но опираются на логику и риторическое мастерство. Иначе говоря, рациональность для Аристотеля становится залогом разрешения конфликтов к обоюдной пользе участвующих в нем сторон.

Обратимся теперь к квинтәссенции диалектической традиции, представленной философией Гегеля. В его учении борьба является необходимостью в развитии духа по направлению к свободе, важнейшей составляющей движения к реализации сверхзаданной цели. В рамках гегелевской диалектики развитие есть процесс, в котором существенную роль играет внутреннее противоречие самого предмета, приводящее в конечном итоге к его коренной трансформации путем приобретения нового качества. Как справедливо отмечает А. Нуццо, именно диалектика является «ключом к пониманию гегелевской герменевтики истории» ${ }^{12}$. Поскольку все разумное действительно, а все действительное - разумно, конфликт в понятии через формы государственности «опрокидывается» в наличную действительность. В связи с этим для Гегеля «...война сохраняет здоровую нравственность народов в их индиффреренции по отношению к определенностям, к их привычности и укоренению подобно тому, как движение ветра предохраняет озера от гниения, которое грозит им при длительном затишье, так же как народам - длительный или тем более вечный мир» ${ }^{13}$. Некоторые современные авторы видят в гегелевском

${ }^{11}$ Аристотель. Риторика. М., 2017. С. 193.

${ }_{12}$ Nuzzo A. Dialectical Reason and Necessary Conflict: Understanding and the Nature of Terror // The Spirit of the Age: Hegel and the Fate of Thinking / ed. by P. Ashton. Melbourne: re.press, 2008. P. 21.

${ }^{13}$ Гегель Г. В. Ф. Политические произведения. М., 1978. С. 229. 


\section{Вестник ВГУ. Серия: Право}

учении элементы современной «реальной политики» или политического реализма ${ }^{14}$. Однако такие заявления совершенно неверно трактуют саму суть гегелевской концепции. Для Гегеля первичным является именно конфликт в сфрере духа, а война является лишь следствием диалектических законов.

Проблема развития через конфликт стала одной из центральных тем философии жизни Г. Зиммеля. В его работе «Конфликт современной культуры», вышедшей одновременно с нашумевшим «Закатом Европы» О. Шпенглера, раскрывается концептуальный каркас модели культуры, несущей в себе неустранимое внутреннее противоречие. Ее динамический характер, с точки зрения Г. Зиммеля, кроется в самой сути жизни как философски осмысленного феномена. Жизнь в культуре есть становящееся развитие, воплощенное и воплощаемое противоречие. Г. Зиммель пишет, что «...жизненная стихия, беспокойная в своем вечном движении, ведет постоянную борьбу со всеми отверделыми остатками, засоряющими ее волну. Но так как она может иметь реальное бытие лишь в определенных формах, то весь этот процесс представляется нашему сознанию как процесс вытеснения старых форм новыми <...> жизнь движется от смерти к бытию и от бытия к смерти» ${ }^{15}$. Конфрликт есть одновременно и содержание, и форма жизни, основной инструмент ее обновления. Анализируя глубинные истоки кризиса культуры начала XX в., о котором писали тогда многие авторы, Г. Зиммель замечает, что мир созданных самим человеком культурных форм приобретает со временем самостоятельное существование, отчуждаясь от субъекта и подавляя его. Бунт против устаревших форм, приводит к переосмыслению культурного опыта, который, в свою очередь, требует фиксации в новых формах. Жизнь в культуре по своей природе не только устанавливает границы, но и взрывает их, реализуя свой экспансионистский потенциал.

Трагический опыт XX в. получил осмысление в различных направлениях фолософской мысли, сложившихся в направление, обозначаемое как философия диалога. В работах Э. Гуссерля, К. Ясперса, М. Мерло-Понти, М. Бахтина, Ж.-Л. Нанси, М. Хайдеггера, Э. Левинаса, Г. Ж.-П. Сартра, О. Розеншток-Хюсси, Ю. Хабермаса был осуществлен поворот от объект-субъектной парадигмы познания и коммуникации к

336 субъект-субъектной модели. Необходимость осмысленного диалога как способа разрешения конфликта в различных сферах человеческого бытия предусматривает новый режим видения целей и задач социального взаимодействия. В связи с этим разработка философской категории Другого становится центром дискурсивного пространства философии диалога. Введенное Э. Гуссерлем понятие интерсубъективности позволяет маркировать пространство "между», в котором разворачивается и осу-

${ }^{14}$ См.: Палан Р. Об идеалистических истоках реалистической теории международных отношений // Неприкосновенный запас. 2005. № 5 (43). URL: http:// magazines.russ.ru/nz/2005/43/pa2.html (дата обращения: 01.10.2020).

15 Зиллель Г. Конфликт современной культуры // Культурология. ХХ век. Антология. М., 1995. С. 379. 
Междисциплинарное сотрудничество...

ществляется диалог между «своим» и «Другим». «Инаковость» Другого, будучи серьезным вызовом, требует особых процедур познания и понимания ${ }^{16}$. Так, О. Розеншток-Хюсси предлагает респонзивный метод, девизом которого является «Respondeo etsi mutabor» («Отвечаю, хотя и должен буду измениться» $)^{17}$. Диалог в его трактовке предусматривает готовность к взаимодействию и трансформации исходных позиций участвующих в нем субъектов. В этом процессе, как и в античные времена, ключевую роль играет речевая деятельность. «Действительный язык означает свободу между двумя людьми варьировать, дополнять взаимообразными путями одно и то же слово, идею, тему или языковой материал, никакая часть ни одного диалога на свете не имеет смысла, если она не воспринимается как вариация чего-то общего, что разделяется говорящим и его слушающими, и в то же время как такая вариация, посредством которой говорящий устремляет людей в новое будущее» ${ }^{18}$.

Пространство медиареальности, которое принято сравнивать с греческой агорой, выступает сегодня по большей части ристалищем перманентных информационных войн. Одной из важнейших задач современной философии является поиск способов переключения в режим диалога, предполагающего агональность как соревнование равных субъектов для выбора наилучших решений социальных проблем.

${ }^{16}$ См.: Ищенко E. Н. Познание Другого : эпистемологические проблемы и социокультурные аппликации // Логос. М., 2005. № 4 (49). С. 172-188.

${ }^{17}$ Розеншток-Хюсси О. Прощание с Декартом // Вопросы философии. 1997. № 8. C. 139 .

${ }_{18}$ Розеншток-Хюсси О. Речь и действительность. М., 1994. С. 53.

Воронежский государственный университет

Ищенко Е. Н., доктор ббилособбских наук, профбессор кафбедрь онтологии $u$ теории познания фбакультета фблософбии и психологии

E-mail: ischenko@phipsy.vsu.ru
Voronezh State University

Ischenko E. N., Doctor of Philosophy, Professor of the Department of Ontology and Theory of Knowledge, Faculty of Philosophy and Psychology

E-mail: ischenko@phipsy.vsu.ru 